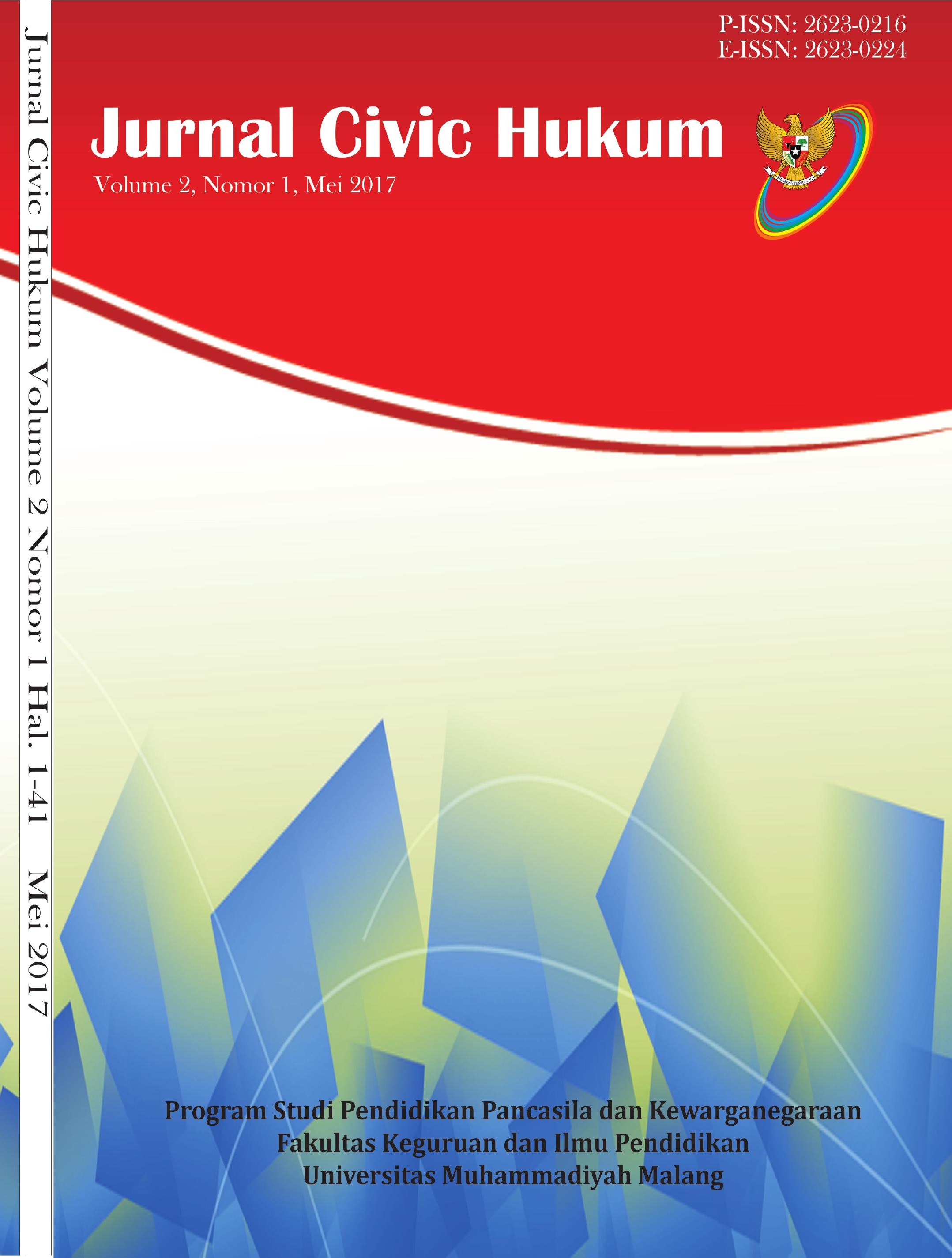


Jurnal Civic Hukum

Volume 2, Nomor 1, Mei 2017

Diterbitkan dua kali dalam setahun, pada bulan Mei dan November oleh Universitas Muhammadiyah Malang dalam satu volume ada dua nomor. Berisi tulisan ilmiah hasil penelitian tentang Pendidikan Kewarganegaraan. Untuk Jurnal Online bisa diakses dilaman : http://ejournal.umm.ac.id/index.php/jurnalcivichukum/index

Ketua Penyunting

Dr. Nurul Zuriah, M.Si.

Wakil Ketua Penyunting

Dr. Budiono, M.Si.

Penyunting Pelaksana

Dr. Agus Tinus, M.Pd.

Dr. M. Syahri, M.Si.

Drs. Nurbani Yusuf, M.Si.

Rose Fitria Lutfiana, M.Pd.

\section{Mitra Bestari}

Dr. Mukhmad Murdiono, S.Pd., M.Pd. (UNY)

Dr. Triyanto, S.H., M.Hum. (UNS)

Dr. Winarno, S.Pd., M.Si. (UNS)

Prof. Dr. Kokom Kumalasari, M.Pd. (UPI)

Dikdik Baehaqi Arif, S.Pd., M.Pd. (UAD)

Dr. Nurwahyu Rochmadi, M.Pd., M.Si. (UM)

Drs. Margono, M.Pd., M.Si. (UM)

Dr. Trisakti Handayani, M.M. (UMM)

\section{Pelaksana Administrasi}

Saputra Tri Kurniawan, M.Pd.

Alamat Penyunting dan Tata Usaha

Kantor Jurnal Civic Hukum Ruang Program Studi PPKn

Jl. Raya Tlogomas 246 Malang 65144, Telp. (0341) 464318; Faksimile (0341) 460782

Pos-el : civich@umm.ac.id dan jurnalcivichukum@gmail.com

Penyunting menerima sumbangan tulisan dari guru dan dosen yang belum pernah dimuat dalam media lain. Naskah ditulis dalam kertas A4 spasi satu antara 10-15 halaman, sesuai dengan format yang tercantum pada halaman belakang ("Petunjuk Penulisan artikel Jurnal Civic Hukum"). Penulis akan mendapatkan nomor bukti penerbitan sebanyak 2 eksemplar.

Dicetak di Percetakan UMM Press. Isi di luar tanggungjawab Percetakan 
Jurnal Civic Hukum

P-ISSN : 2623-0216

E-ISSN : 2623-0224

Volume 2, Nomor 1, Mei 2017

Daftar Isi

Implementasi Pendidikan Karakter Berbasis Budaya Religius

Aris Sahruli, Rohmad Widodo, Budiono

Implementasi Tata Tertib Sekolah Dalam Meningkatkan karakter Kedisiplinan Siswa

Moh. Mansyur Fawaid

Pembentukan Karakter Siswa Melalui Kegiatan Positive Character Camp (PCC)

Ramdhani Andarus Abbas, M. Mansur, Budiono

Peran Guru PPKn dalam Mengembangkan Nilai - Nilai Wawasan Kebangsaan dan Rasa Cinta Tanah Air

Rani Asmara Hanipasa, Rohmad Widodo, Nurul Zuriah

Peranan Pendidikan Kewarganegaraan (PKn) Dalam Pembentukan Moral Peserta Didik

Yuliana Syamsul, Rohmad Widodo, Agus Tinus 